\title{
The association between serum calcium and chronic heart failure: A cross-sectional observational study \\ Madhura $\mathrm{AR}^{1}$, Veeranna Gowda $\mathrm{KM}^{2}$, and Jayachandra $\mathrm{V}^{2}$ \\ ${ }^{1}$ Department of General Medicine, Mother Hospital, Thrissur, Kerala-680012, India \\ ${ }^{2}$ Department of General Medicine, Bangalore Medical College and Research Institute, Bengaluru, Karnataka-560002, India
}

\begin{abstract}
Background: Chronic heart failure (CHF) is characterized by sustained activation of neurohormonal and cytokine systems leading to a series of end-organ changes within the myocardium referred to as left ventricular remodeling. Renin-Angiotensin system activation leading to secondary hyperaldosteronism is accompanied by ionized hypocalcemia with secondary hyperparathyroidism which causes dyshomeostasis of extra and intracellular calcium leading to cardiomyocyte necrosis.
\end{abstract}

Objectives: To study the levels of serum calcium in patients of heart failure and its association with severity and duration of chronic heart failure.

Methods: The study was conducted on 50 patients with CHF after taking informed consent. All patients met inclusion and exclusion criteria and underwent blood sampling, urine examination and other relevant investigations. Serum calcium levels were correlated with the severity and duration of CHF statistically.

Results: Among the patients studied, 96\% with ejection fraction (EF) $\leq 35 \%, 87.5 \%$ with EF between $35-40 \%$ and $44.4 \%$ with $\mathrm{EF} \geq 40 \%$ had low serum calcium values $\leq 9 \mathrm{mg} / \mathrm{dl}$ ( $\mathrm{p}$-value $<0.001$ ). All patients with duration of heart failure $\geq 2$ years and $70.4 \%$ patients with duration of heart failure 1-2 years had low serum calcium levels $\leq 9 \mathrm{mg} / \mathrm{dl}$ ( $\mathrm{p}$ value $=0.001)$.

Conclusion: There is a significant positive correlation of serum calcium levels with severity of heart failure as measured by EF and significant negative correlation with duration of CHF and NYHA functional grades. The degree of hypocalcemia correlates with severity of cardiomyocyte injury and extent of the neurohormonal response, and accordingly the corresponding risk of adverse cardiovascular events.

Keywords: duration of chronic heart failure; ejection fraction; NYHA grade; serum calcium

*Corresponding author: Dr. Madhura AR, Senior Resident, Department of General Medicine, Mother Hospital, Thrissur, Kerala-680012, India. Mobile: +91 9611847280; Email: madhura140@gmail.com

Received 11 January 2021; Revised 1 March 2021; Accepted 9 March 2021; Published 17 March 2021

Citation: Madhura AR, Gowda KMV, Jayachandra V. The association between serum calcium and chronic heart failure: $A$ cross-sectional observational study. J Med Sci Res. 2021; 9(2):9195. DOI: http://dx.doi.org/10.17727/JMSR.2021/9-14

Copyright: (C) 2021 Madhura AR et al. Published by KIMS Foundation and Research Center. This is an open-access article distributed under the terms of the Creative Commons Attribution License, which permits unrestricted use, distribution, and reproduction in any medium, provided the original author and source are credited. 


\section{Introduction}

Chronic heart failure (CHF) is a progressive disorder that is initiated after an index event which either damages the heart muscle, with a resultant loss of functioning cardiac myocytes, or disrupts the ability of the myocardium to generate force, thereby preventing the heart from contracting normally [1]. The decrease in cardiac output in HF activates a series of compensatory adaptations that are intended to maintain cardiovascular homeostasis. One of the most important adaptations is activation of the sympathetic (adrenergic) nervous system, which occurs early in the course of HF. In contrast to the sympathetic nervous system, the components of the Renin-Angiotensin system (RAS) are activated comparatively later in HF [2]. The presumptive mechanisms for RAS activation in HF include renal hypoperfusion; decreased filtered sodium reaching the macula densa in the distal tubule; and increased sympathetic stimulation of the kidney, leading to increased renin release from the juxtaglomerular apparatus [3]. Persistent neurohormonal activation involving the RAS and sympathetic nervous system occurs with protracted CHF causing a dyshomeostasis of divalent cations. These include plasma-ionized hypocalcemia and hypomagnesemia that account for secondary hyperparathyroidism (SHPT) and elevated plasma parathyroid hormone (PTH) levels, together with hypovitaminosis $D$ that further compromises calcium $\left(\mathrm{Ca}^{2+}\right)$ balance, hypozincemia, and hyposelenemia [4-8]. Aldosterone promotes epithelial cell $\mathrm{Na}^{+}$channelmediated $\mathrm{Na}+$ reabsorption without influencing $\mathrm{Ca}^{2+}$ and magnesium $\left(\mathrm{Mg}^{2+}\right)$ excretion, which in turn accounts for the marked urinary losses of $\mathrm{Ca}^{2+}$ and $\mathrm{Mg}^{2+}[9,10]$. A similar scenario unfolds in the $\mathrm{Na}^{+}$ channels of the colon's epithelial cells that represent another site of high-density aldosterone receptor binding. The fecal excretion of $\mathrm{Ca}^{2+}$ and $\mathrm{Mg}^{2+}$, in fact, is many-fold greater than their urinary losses. The calcium-sensing receptor of the parathyroid glands, in turn, responds to hypocalcemia with increased secretion of parathyroid hormone (PTH) [11-16]. In cardiomyocytes, these calcitropic hormones, however, simultaneously promote L-type $\mathrm{Ca}^{2+}$ channel activity leading to increased cytosolic free $\mathrm{Ca}^{2+}$ and, in turn, mitochondrial $\mathrm{Ca}^{2+}$ overloading with organellar-based oxidative stress. Normally, excessive intracellular calcium accumulation (EICA) is minimized by intracellular autoregulatory responses, wherein the rate of $\mathrm{Ca}^{2+}$ influx is limited by specific and specialized L-type $\mathrm{Ca}^{2+}$ channels of an otherwise impermeable sarcolemma membrane which is in equilibrium with the rate of $\mathrm{Ca}^{2+}$ efflux $[17,18]$. Cardiomyocyte necrosis occurs when the imbalance between $\mathrm{Ca}^{2+}$ influx-efflux and $\mathrm{Ca} 2+$ storage capacity of mitochondria is lost. In mitochondria, $\mathrm{Ca}^{2+}$ overloading and oxidative stress also lead to a nonphysiologic opening of the MPTP (mitochondrial permeability transition pore) with the ensuing osmotic-based structural and functional degeneration of these organelles [19-22]. Thus PTHmediated intracellular $\mathrm{Ca}^{2+}$ overloading is coupled to an induction of oxidative stress in cardiomyocytes and their mitochondria that triggers the downhill final common cell death pathway leading to cardiomyocyte necrosis and subsequentreplacement fibrosis. The degree of plasma ionized hypocalcemia and accompanying elevations in plasma PTH can serve as markers of myocyte injury which is the key component in left ventricular remodelling taking place in chronic heart failure.

\section{Methodology}

This was a cross-sectional study conducted on 50 patients diagnosed to have CHF based on history, clinical examination and 2-D echocardiography after taking written and informed consent. They were categorized based on duration of symptoms, NYHA functional classification and the severity of heart failure measured in terms of ejection fraction. Relevant data about diabetes mellitus, hypertension and renal disease was taken in the history. Serum calcium, complete blood count (CBC), urine microscopy, renal function test (RFT), liver function test ( LFT ), random blood sugar (RBS), serum electrolytes, lipid profile, serum PTH levels were done for all patients and thyroid function tests wherever applicable. All serum calcium values were corrected for patient's serum albumin levels. The patients included were older than 18 years of age, had CHF symptoms for more than one year, belonged to New York Heart Association (NYHA) functional class II and III with echocardiographically assessed left ventricular ejection fraction $\leq 45 \%$.

The exclusion criteria included: (1) Clinically suspected primary hyperparathyroid states, (2) Patients with renal failure, uremia, (3) Lithium therapy, aluminium intoxication, (4) Clinical 
suspicion of malignancy: Multiple myeloma, lymphoma, leukemia, tumours oflung, kidney, breast, (5) Vitamin D related: intoxication, clinical suspicion of sarcoidosis \& other granulomatous diseases, (6) High bone turn over states: hyperthyroidism, thiazides, immobilisation, vitamin A intoxication.

\section{Statistical analysis}

Descriptive statistical analysis has been carried out in the present study. Results on continuous measurements are presented as Mean \pm SD (MinMax) and results on categorical measurements are presented in number (\%). Significance is assessed at $5 \%$ level of significance. $P$ value $<0.05$ is taken as significant. Chi-square test has been used to find the significance of study parameters on categorical scale between two or more groups. Fisher's exact t-test has been used wherever Chi-square assumptions have failed. Pearson correlation co-efficient has been used to establish correlation between the variables and its significance has been tested. Results are analysed using SPSS Software for Windows. Classification of Correlation co-efficient (r): 0.1-0.3 = small correlation, $0.3-0.5=$ moderate correlation, $0.5-0.7=$ large correlation, $0.7-0.9=$ very large correlation, $0.9-1.0=$ nearly perfect correlation and $1=$ perfect correlation. Significant figures: $p$-value $\leq 0.01=$ strongly significant, $0.01-0.05=$ moderately significant and 0.05-0.10= suggestive significance.

\section{Results}

Among the 50 patients studied, $50 \%(\mathrm{n}=25)$ were males and $50 \%(n=25)$ were females. $56 \%(n=28)$ of the study population were diabetic and hypertensive. $90 \%(\mathrm{n}=45)$ had duration of heart failure for $\geq 2$ years. $50 \%(\mathrm{n}=25)$ were in NYHA functional classification Grade II and the other 50\% ( $\mathrm{n}=25)$ were in Grade III. $50 \%(n=25)$ of them had an ejection fraction of $\leq 35 \%, 32 \%(n=16)$ of them between $35-40 \%$ and the remaining $18 \%(n=9) \geq 40 \%$. Among the study population, $96 \%$ (24 out of 25 ) of patients with EF $\leq 35 \%, 87.5 \%$ (14 out of 16 ) of patients with EF between $35-40 \%$ and $44.4 \%$ (4 out of 9) patients with $\mathrm{EF} \geq 40 \%$ had low serum calcium values $\leq 9$ $\mathrm{mg} / \mathrm{dl}$ (Table 1). There was a significant correlation between low EF and low serum calcium values with $\mathrm{p}$-value $=0.001$ (Chi-square $=13.3$ ).

Comparison of ejection fraction and serum calcium among the study population (Table 1) 96\% (24 out of 25) of the patients in NYHA functional Grade III had low serum calcium values $(\leq 9 \mathrm{mg} / \mathrm{dl}$ ) with the mean of $7.9 \pm 0.6 \mathrm{mg} / \mathrm{dl} .72 \%$ (18 out of 25 ) patients in NYHA functional Grade II had mean serum calcium values of $8.7 \pm 0.6 \mathrm{mg} / \mathrm{dl}$ (Table 2). There was a significant correlation with increasing NYHA Grade and low serum calcium levels with $p$-value $<0.001$.

Table 1: Comparison of ejection fraction and serum calcium among the study population.

\begin{tabular}{|ccc|}
\hline $\begin{array}{c}\text { Ejection } \\
\text { fraction (\%) }\end{array}$ & $\begin{array}{c}\text { Number of patients } \\
\text { with serum calcium } \\
(\leq 9 \mathrm{mg} / \mathrm{dl})\end{array}$ & $\begin{array}{c}\text { Number of patients } \\
\text { with serum calcium } \\
(>9 \mathrm{mg} / \mathrm{dl})\end{array}$ \\
\hline$\leq 35(\mathrm{n}=25)$ & $24(96.0 \%)$ & $1(4.0 \%)$ \\
$35-40(\mathrm{n}=16)$ & $14(87.5 \%)$ & $2(12.5 \%)$ \\
$\geq 40(\mathrm{n}=09)$ & $4(44.4 \%)$ & $5(55.6 \%)$ \\
\hline
\end{tabular}

Table 2: Comparison of serum calcium between NYHA grades.

\begin{tabular}{|lcc|}
\hline NYHA & $\begin{array}{c}\text { Number of patients } \\
\text { with serum } \\
\text { calcium }(\leq 9 \mathrm{mg} / \mathrm{dl})\end{array}$ & $\begin{array}{c}\text { Number of patients } \\
\text { with serum } \\
\text { calcium }(>9 \mathrm{mg} / \mathrm{dl})\end{array}$ \\
\hline Grade II $(\mathrm{n}=25)$ & $18(72.0 \%)$ & $7(28.0 \%)$ \\
Grade III $(\mathrm{n}=25)$ & $24(96.0 \%)$ & $1(4.0 \%)$ \\
\hline
\end{tabular}

All the patients $(\mathrm{n}=23)$ with duration of heart failure $\geq 2$ years and $70.4 \%$ (19 out of 27) of patients with duration of heart failure 1-2 years had low serum calcium levels $\leq 9 \mathrm{mg}$ / dl (Table 3). There was a significant correlation between the two variables with a $p$-value $=0.001$ (Fisher exact test).

Table 3: Relation of serum calcium with duration of symptoms.

\begin{tabular}{|ccc|}
\hline Duration & $\begin{array}{c}\text { Number of } \\
\text { patients with } \\
\text { serum calcium }(\leq \\
9 \mathrm{mg} / \mathrm{dl})\end{array}$ & $\begin{array}{c}\text { Number of } \\
\text { patients with } \\
\text { serum calcium }(>9 \\
\mathrm{mg} / \mathrm{dl})\end{array}$ \\
\hline $1-2$ years $(\mathrm{n}=27)$ & $19(70.4 \%)$ & $8(29.6 \%)$ \\
$\geq 2$ years $(\mathrm{n}=23)$ & $23(100.0 \%)$ & $0(0.0 \%)$ \\
\hline
\end{tabular}

All the patients $(n=21)$ with diabetes mellitus and $\mathrm{EF} \leq 35 \%, 85.7 \%$ ( 6 out of 7 ) of patients with diabetes mellitus and $\mathrm{EF}>35 \%, 68.2 \%$ (15 out of 22 ) of non-diabetic patients had low serum calcium $\leq 9$ $\mathrm{mg} / \mathrm{dl}$ (Table 4). There was a significant correlation between diabetes with $\mathrm{EF} \leq 35 \%$ and low serum calcium values with a $p$-value $=0.017$ (Chi-square $=8.11)$. All the patients $(n=14)$ with hypertension and $\mathrm{EF} \leq 35 \%, 78.6 \%$ (11 out of 14 ) of patients with hypertension and $\mathrm{EF}>35 \%$ and $77.3 \%$ (17 out of 22 ) of normotensive patients had low serum calcium $\leq 9$ $\mathrm{mg} / \mathrm{dl}$ (Table 4). There was no significant correlation between hypertension and low serum calcium values with a $\mathrm{p}$ value $=0.156($ Chi-square $=3.71)$. 
Table 4: Effect of diabetes and hypertension in patients with $\mathrm{CHF}$ and its relation to serum calcium.

\begin{tabular}{|ccc|}
\hline & $\begin{array}{c}\text { Number of patients } \\
\text { with serum calcium } \\
(\leq 9 \mathrm{mg} / \mathrm{dl})\end{array}$ & $\begin{array}{c}\text { Number of } \\
\text { patients with } \\
\text { serum calcium } \\
(>9 \mathrm{mg} / \mathrm{dl})\end{array}$ \\
\hline $\begin{array}{c}\text { Diabetics } \\
\mathrm{EF} \leq 35 \%(\mathrm{n}=21)\end{array}$ & $21(100.0 \%)$ & $0(0.0 \%)$ \\
$\mathrm{EF}>35 \%(\mathrm{n}=7)$ & $6(85.7 \%)$ & $1(14.3 \%)$ \\
$\begin{array}{c}\text { Non-diabetics } \\
(\mathrm{n}=22)\end{array}$ & $15(68.2 \%)$ & $7(31.8 \%$ \\
Hypertensives & $14(100.0 \%)$ & $0(0.0 \%)$ \\
$\mathrm{EF} \leq 35 \%(\mathrm{n}=14)$ & $11(78.6 \%)$ & $3(21.4 \%)$ \\
$\begin{array}{c}\mathrm{EF}>35 \%(\mathrm{n}=14) \\
\text { Non-hypertensives } \\
(\mathrm{n}=22)\end{array}$ & $17(77.3 \%)$ & $5(22.7 \%)$ \\
\hline
\end{tabular}

There was a significant positive correlation between serum calcium and severity of heart failure as measured by ejection fraction with $r$ value $=0.909$. There was a significant negative correlation of serum calcium with the duration of heart failure ( $p$-value $<0.001$ ) and serum calcium with NYHA functional grades ( $\mathrm{p}$-value $<0.001$ ).

\section{Discussion}

A total of 50 patients above the age group of 18 years predominantly between 46-60 years who were diagnosed to have CHF of different etiologies for a period of more than one year were studied. Among them, 50\% were males and 50\% were females. $56 \%$ of the study population were diabetic and hypertensive. In our study, normal calcium levels were defined between $9-10.5 \mathrm{mg} / \mathrm{dl} .96 \%$ of patients with $\mathrm{EF} \leq 35 \%, 87.5 \%$ of patients with EF between $35-40 \%$ and $44.4 \%$ patients with $\mathrm{EF} \geq 40 \%$ had low serum calcium values $\leq 9 \mathrm{mg} / \mathrm{dl}$. $96 \%$ of the patients in NYHA functional Grade III and $72 \%$ patients in NYHA functional Grade II had low serum calcium values $\leq 9 \mathrm{mg} / \mathrm{dl}$. All the patients with duration of heart failure $\geq 2$ years and $70.4 \%$ of patients with duration of heart failure 1-2 years had low serum calcium levels $\leq 9 \mathrm{mg} / \mathrm{dl}$.

Jensen et al [23] identified 2729 chronic heart failure patients from Danish National Registries and analysed their serum calcium values. The highest mortality risk was present in early deaths ( $\leq 30$ days), with a HR of 2.22 (95\% CI; 1.74-2.82) in hypocalcemic patients and 1.67 (95\% CI; 0.962.90) in hypercalcemic patients compared with normocalcemic patients. They concluded that altered calcium homeostasis was associated with an increased short-term mortality risk and almost onethird of all the heart failure patients suffered from hypocalcemia, having a poor prognosis. Liu et al [24] conducted a study involving 350 patients with newly diagnosed HFpEF to reveal the association of serum calcium concentration at baseline with 12-month clinical outcome in the disease. Baseline hypocalcaemia was associated with the increased risk of cardiac re-hospitalization and death during the follow-up period (HR: 2.10, 95\% CI: 1.69-2.61; HR: 8.26, 95\% CI: 2.88-23.70). There was also deterioration of 6-minute walk distance, quality of life score (EQ-5D), left atrium volume index and left ventricular ejection fraction during the followup period. Miura et al [25] studied 191 patients of heart failure with chronic kidney disease (CKD) and showed that the low-Ca $(<8.4 \mathrm{mg} / \mathrm{dl})$ group had higher levels of alkaline phosphatase $(308.9$ vs $261.0 \mathrm{U} / \mathrm{L} ; \mathrm{P}=0.026$ ), lower levels of 1,25 dihydroxy vitamin $\mathrm{D}$ (26.1 vs $45.0 \mathrm{pg} / \mathrm{mL} ; \mathrm{p}=0.011$ ) and hydrogen carbonate (22.4 vs $24.5 \mathrm{mmol} / \mathrm{L}$; $\mathrm{p}=0.031$ ), and a tendency to have a higher PTH level (87.5 vs 58.6 pg/mL; p=0.084). In the KaplanMeier analysis, cardiac and all-cause mortality were significantly higher in the low-Ca group than in the normal-high-Ca group ( $p<0.05)$. In the multivariable Cox proportional hazard analyses, hypocalcemia was an independent predictor of allcause mortality in HF and CKD patients ( $<<0.05)$. Garakyaraghi et al [26] studied 28 women and 67 men of CHF with NYHA functional classes I, II and III. Patients with hyperparathyroidism (serum PTH $>65$ $\mathrm{ng} / \mathrm{L}$ ) induced by hypocalcemia had lower LVEF ( $27 \%$ versus $32.5 \% \mathrm{p}=0.03)$. NYHA functional class was worse in patients with hyperparathyroidism $(p=0.08)$. Wannamethee et al [27] conducted a prospective study of 3731 men aged 60 to 79 years with no prevalent HF for a mean period of 13 years, in whom there were 287 incident HF cases. Elevated PTH ( $\geq 55.6 \mathrm{pg} / \mathrm{mL}$ ) secondary to hypocalcemia was associated with significantly higher risk of incident HF (hazards ratio, 1.66; 95\% confidence interval, 1.30-2.13).

Our study results are comparable with the other clinical studies [23-27] showing that hypocalcemia triggers a cascade of the release of calcitropic hormones which cause excessive intracellular $\mathrm{Ca}^{2+}$ accumulation (EICA) and increased oxidative stress in the cardiomyocytes. This results in myocyte necrosis exacerbating the pathophysiology of heart failure. Persistent RAS activation as the CHF 
advances, further decreases the serum calcium and contributes to left ventricular remodeling. Even though our study is limited by smaller sample size, it provides understanding of the pathophysiology of $\mathrm{CHF}$ at cellular and molecular levels.

\section{Conclusion}

Calcium is an essential intracellular messenger, especially in contractile cells, such as cardiomyocytes. However, an excessive accumulation of calcium becomes a cellular toxin. The responses invoked by ionised hypocalcemia trigger oxidative stress and cause myocyte necrosis in a failing heart. The degree of hypocalcemia has a positive correlation with the severity and duration of heart failure. Serum calcium can be used as an independent marker for severity assessment in CHF.

\section{Conflicts of interest}

Authors declare no conflicts of interest.

\section{References}

[1] Zipes DP, Libby P, Bonow RO, Mann DL, Tomaselli GF, et al. Pathophysiology of heart failure. In: Braunwald's heart disease: A textbook of cardiovascular medicine. 11th ed. Elsevier; 2019; p.424-440.

[2] Kasper DL, Fauci AS, Hauser SL, Longo DL, Jameson JL, et al. Harrison's principles of Internal Medicine. 20th ed. New York: McGraw-Hill, 2018.

[3] Ashrafian H, Frenneaux MP, Opie LH. Metabolic mechanisms in heart failure. Circulation. 2007; 116(4):434-448.

[4] LaGuardia SP, Dockery BK, Bhattacharya SK, Nelson MD, Carbone LD, et al. Secondary hyperparathyroidism and hypovitaminosis D in African-Americans with decompensated heart failure. Am J Med Sci. 2006; 332(3):112-118.

[5] Arroyo M, LaGuardia SP, Bhattacharya SK, Nelson MD, Johnson PL, et al. Micronutrients in African-Americans with decompensated and compensated heart failure. Transl Res. 2006; 148(6):301-308.

[6] Alsafwah S, LaGuardia SP, Nelson MD, Battin DL, Newman $\mathrm{KP}$, et al. Hypovitaminosis D in African Americans residing in Memphis, Tennessee with and without heart failure. Am J Med Sci. 2008; 335(4):292-297.

[7] Kamalov G, Ahokas RA, Zhao W, Johnson PL, Shahbaz AU, et al. Temporal responses to intrinsically coupled calcium and zinc dyshomeostasis in cardiac myocytes and mitochondria during aldosteronism. Am J Physiol Heart Circ Physiol. 2010; 298(2):H385-H394.

[8] Kamalov G, Deshmukh PA, Baburyan NY, Gandhi MS, Johnson $\mathrm{PL}$, et al. Coupled calcium and zinc dyshomeostasis and oxidative stress in cardiac myocytes and mitochondria of rats with chronic aldosteronism. J Cardiovasc Pharmacol. 2009; 53(5):414-423.

[9] Vidal A, Sun Y, Bhattacharya SK, Ahokas RA, Gerling IC, et al. Calcium paradox of aldosteronism and the role of the parathyroid glands. Am J Physiol Heart Circ Physiol. 2006; 290(1):H286-H294.

[10] Fujita T, Palmieri GM. Calcium paradox disease: calcium deficiency prompting secondary hyperparathyroidism and cellular calcium overload. J Bone Miner Metab. 2000 18(3):109-125.
[11] Loncar G, Bozic B, Dimkovic S, Prodanovic N, Radojicic Z, et al. Association of increased parathyroid hormone with neuroendocrine activation and endothelial dysfunction in elderly men with heart failure. J Endocrinol Invest. 2011; 34(3):e78-85.

[12] Bozic B, Loncar G, Prodanovic N, Lepic T, Radojicic Z, Cvorovic $\mathrm{V}$ et al. Parathyroid hormone response to vitamin D insufficiency in elderly males with chronic heart failure. Physiol Res 2011; 60 Suppl 1:S155-S163.

[13] Anderson JL, Vanwoerkom RC, Horne BD, Bair TL, May HT, et al. Parathyroid hormone, vitamin D, renal dysfunction, and cardiovascular disease: dependent or independent risk factors? Am Heart J. 2011; 162(2):331-339.e2.

[14] Altay H, Zorlu A, Binici S, Bilgi M, Yilmaz MB, et al. Relation of serum parathyroid hormone level to severity of heart failure. Am J Cardiol. 2012; 109(2):2526.

[15] Sugimoto T, Tanigawa T, Onishi K, Fujimoto N, Matsuda A, et al. Serum intact parathyroid hormone levels predict hospitalisation for heart failure. Heart. 2009; 95(5):395398.

[16] Altay H, Zorlu A, Bilgi M, Erol T, Yilmaz MB. Usefulness of parathyroid hormone as a predictor of heart failure with preserved ejection fraction. Biomarkers. 2012; 17(5):447454.

[17] Yusuf J, Khan MU, Cheema Y, Bhattacharya SK, Weber KT. Disturbances in calcium metabolism and cardiomyocyte necrosis: the role of calcitropic hormones. Prog Cardiovasc Dis. 2012; 55(1):77-86.

[18] Nakayama H, Chen X, Baines CP, Klevitsky R, Zhang X, et al. $\mathrm{Ca} 2+$ and mitochondrial dependent cardiomyocyte necrosis as a primary mediator of heart failure. J Clin Invest. 2007; 117(9):2431-2444

[19] Gandhi MS, Kamalov G, Shahbaz AU, Bhattacharya SK, Ahokas RA, et al. Cellular and molecular pathways to myocardial necrosis and replacement fibrosis. Heart Fail Rev. 2011; 16(1):23-34.

[20] Javadov S, Karmazyn M, Escobales N. Mitochondrial permeability transition pore opening as a promising therapeutic target in cardiac diseases. J Pharmacol Exp Ther. 2009; 330(3):670-678.

[21] Carlstedt F, Lind L, Rastad J, Stjernström H, Wide L, et al. Parathyroid hormone and ionized calcium levels are related to the severity of illness and survival in critically ill patients. Eur J Clin Invest. 1998; 28(11):898-903.

[22] Zia AA, Komolafe BO, Moten M, Ahokas RA, McGee JE, et al. Supplemental vitamin D and calcium in the management of African Americans with heart failure having hypovitaminosis D. Am J MedSci. 2011; 341(2):113-118.

[23] Jensen ASC, Polcwiartek C, Søgaard P, Mortensen RN, Davidsen $\mathrm{L}$, et al. The association between serum calcium levels and short-term mortality in patients with chronic heart failure. Am J Med. 2019; 132(2):200-208.

[24] Liu F, Zhang H, Li Y, Lu X. Hypocalcaemia predicts 12-month re-hospitalization in heart failure. Eur J Clin Invest. 2020; 50(8):e13261.

[25] Miura S, Yoshihisa A, Takiguchi M, Shimizu T, Nakamura Y, et al. Association of Hypocalcemia With Mortality in Hospitalized Patients with Heart Failure and Chronic Kidney Disease. Journal of Cardiac Failure. 2015; 21(8):621-627.

[26] Garakyaraghi M, Kerdegari M, Siavash M. Calcium and vitamin D status in heart failure patients in Isfahan, Iran. Biol Trace Elem Res. 2010; 135(1-3):67-73.

[27] Wannamethee SG, Welsh P, Papacosta O, Lennon L, Whincup $\mathrm{PH}$, et al. Elevated parathyroid hormone, but not vitamin D deficiency, is associated with increased risk of heart failure in older men with and without cardiovascular disease circulation. Clin Heart Fail. 2014; 7(5):732-739. 